\title{
Privatization of Banking Sector in Pakistan- A Case Study of MCB Bank Limited
}

\author{
Prof Muhammad Ishaque Bajoi
}

Ph D Scholar Department of Economics, University of Sindh Jamshoro

\section{Prof Dr Ambreen Zaib Khaskelly}

\author{
Supervisor. Chairperson University of Sindh, Department of Economics University of Sindh Jamshoro
}

\begin{abstract}
This research study aimed at to explore the performance and efficiency of selected sample bank after its privatization. Privatization is the process to sale and transfers the assets of public sector entities to private sector to boost the laissez fair economy in line with international trends in the wake of failure of socialism and communism.
\end{abstract}

Pakistan's banking sector was performing very poor after the nationalization of banks in 1974 and witnessed financial indiscipline due to political interference in day to day activities particularly in hiring and lending which badly affected the quality of service on one hand and accumulation of bad debts on other. Therefore need was felt to privatize the state owned organizations with main objective to restrict the role government interference so that performance of banking industry of the country could be improved.

Prior researchers worked a lot to identify the positive and negative effects of privatization on the performance of newly privatized firms' globally. This research has been carried out to evaluate and assess the performance of MCB (Formerly Muslim Commercial Bank Limited) after privatization. The research revealed that bank has performed very well in terms of growth, profitability, liquidity and solvency. Financial ratios have been used to evaluate the performance and efficiency and were represented by using graphs. Software SPSS (statistical package for social science) was also used to gauge and find descriptive \& graphical analysis. It was concluded that bank has shown tremendous growth in building deposits base, generating profits and ensuring long term solvency.

\section{Key Words: Privatization, MCB Bank Limited, Non Performing Loans,CAR ,Deposits ,Assets ,Profitability INTRODUCTION}

Privatization refers to the sale and transfer of shares \& assets of sate owned enterprise to the private sector may include individuals and firms as well, this is a narrow concept broadly it means restriction of state interference in the affairs of privatized /private firms to boost the concept of free economy.

In last few decades the governments have undergone some radical changes after collapse of socialism and communism worldwide. Hence government's direct role in deciding the directions of economy has been restricted and replaced by laissez fair. It does not mean that no role of government at all but a better and beneficial role to allow the organization to flourish in competitive manner to offer better goods and services to its people. Further it encourages innovation and use of modern technology in new global village where goods and services are provided at the click of a button.

Pakistan's banking sector was performing very poor after the nationalization of banks in 1974 and witnessed financial indiscipline due to political interference in day to day activities particularly in hiring and lending which badly affected the quality of service on one hand and accumulation of bad debts on other especially DFIs and NCBs contributed a lot in Non Performing Loans (NPLs) accounted for around $90 \%$ of banking industry.

Therefore it was initially decided to privatize two relatively small banks ABL \& MCB in terms of business in initial phase in 1991.

\section{Need for Privatization}

Generally the state has one or more of the following objectives of privatization;

I) Strengthening of private sector. To strengthen private sector government of Pakistan carried out privatization in 1960s by establishing factories strategically and handed over to private sector on concessional rates as the business class was reluctant enough to enter into such sectors having risk sensitive and the private sector was lacking the resources.

II) Improving the efficiency: Government offered incentives and reward to private sector that were expected to inject capital in SOEs and improve technology for better service through enhanced management style and practices.

III) Reduction/Elimination of the state subsidies: Government was compelled to support SOEs which were running in loss continuously and could not be closed either for strategic nature or working for social welfare.

IV) Raising funds in capital market

Funds are raised in local as well as international capital market by way of divesting shares of the profitable government enterprises/ Sate Owned Enterprises (SOEs). Privatization of an SOE for strengthening the private sector cannot be evaluated for the amount of funds it brought to the state. 


\section{Potential Benefits of Privatization}

\section{Improved Efficiency}

Private entities use to manage its affairs with utmost prudence and austerity whereas governments run the business without considering the cost profit analysis of the activities which ultimately adversely affects the efficiency and performance of SOEs in contrast to privatized organizations.

\section{Lack of Political Interference}

The most common pressure on SOEs is hiring of employees on the political recommendation which may result into over recruitment and inefficiency. Although government wants to get rid of excess staff by firing but due to negative propaganda and hue and cry of job losses it is compromised.

\section{Short Term view}

It is also argued that government often interested in short term plans and projects to reap the fruit in coming elections instead of strategic thinking and long term policies such as infrastructure development which will benefit to the masses in long run.

\section{Shareholders}

Since there is an interest of all stake holders in an entity particularly in private organization the stock holders are keenly interested on better return on their investment hence they have an indirect pressure on management for better performance in terms of profit as compare to SOEs.

\section{Increased Competition}

It is generally agreed that with deregulation and privatization monopolies no more exist in market place and it encourages more firms to participate and enter in market for healthy competition that ultimately spur the improvement in overall efficiency.

\section{Objectives of Study}

What will be the impact of Privatization on overall performance and efficiency of sample bank?

What will be its impact on innovation and services?

What will be its effect on building customer base?

What will be the impact on growth of the bank in terms of profitability and equity building?

\section{REVIEW OF LITERATURE}

When policy makers started Privatization of financial institutions many researchers worked globally to explore its possible effects on various aspects. It was a big question whether privatization is favorable to financial markets or otherwise. Efficiency and performance of sector under review was evaluated by number of scholars by using different tools \& techniques.

Megginson, Nash, and Van randen borgh (1994) have carried out their research to analyze the impact of privatization on performance of banks. They have selected 61 firms and 320indusrial units operating in 18 different countries, financial statements of three years were used for research purpose. It was concluded that performance was improved in terms of profitability and operating output after privatization of the selected sample firms.

Boubarki and Cosset (1998) also worked on same pattern by selecting 79 units from 21 different economies. They also used same technique of three years annual accounts which were analyzed by using financial ratios for the period before and after privatization. It was concluded that privatization has positively affected the performance and efficiency of firms.

D' Souza and Megginson (1999) conducted same nature research by taking 78 units from 10 countries for the period of five years and concluded that performance was enhanced during the period after privatization..

Cook, Hababon and Roberts (2001).in their research study concluded Tunisian banking system has no visible positive change after liberalization however privatized banks had shown more performing efficiency than state controlled banks.

According to Levine (1997) and Gertler (1988) efficient and disciplined financial market has positive impact on economic growth.

LaPorta, Lopez-deSilanes,Shleifer(2000a) worked on 92 financial institutes of developing as well as developed countries to examine the impact of state owned banks on the efficiency and performance of banks and economic development and growth. It was explored that it has adverse impact on efficiency, performance and economic growth especially in poor and under developing countries. 

Rajan and Zingales (1998) explored that financial sector have direct impact on economic growth of country. They further added that strong and resilient banking system is prerequisite for modern age trade and commerce which ultimately supports towards economic growth.

Cetorelli and Gambera (2001) and Beck,Demirguc-Kunt and Levine (2003) have researched on this hot issue and explored that regulatory frame work is very much essential for liquid and efficient banking sector and capital markets as well. Further the concluded that well disciplined and efficient financial system is helpful in achievement of economic growth of country.

Baily, 1986, Peltzman, 1989, Winston, 1993,1998 in their research concluded that state's role and intervention have an adverse impact on the performance of the financial sector which also hits the overall growth of economy and financial sector reforms must be need based which are linked with economic directions set by state. The role of state in directing banks and financial institutions must be minimal and managers of financial sector should be empowered to take their own decisions on the basis of business considerations which ultimately supports in macro economic conditions of the country.

Peng, 2000; Svenjar, 2002 has concluded that laissez fair economy has positive impact on economic growth rather than commanded one which will aid in market based dicisions and will be helpful in economic growth and development of the country and financial system as well..

Svejnar and Terrel 1991, Hess 1994Beck, Johanson and Fretwell 1995; Van der Hoeven and Sziracki 1997 explored that policy makers and academic circles have ignored the importance of employees ,focused on impact of privatization ,workforce faced several severe nature consequence in changed scenario such as job security, staff welfare, pay and perks etc which caused manpower turnover.

Sunita Kikeri, in her Technical Paper No. 396. World Bank, Washington, D.C., February (1998) shed lights on the adverse effects on work force after privatization and concluded that cost cutting is transferred to employees and workforce is not paid equitably.

Robin Johnson, E-brief 112 (2001) carried out research work and concluded that the policies adopted under state ownership are not necessarily be discontinued and employees fire in many cases seems to be unjust but in long run the policies for pay for performance conditions that employer keep the fair system of reward in place without biased.

According to Gopal Joshi Geneva, (2000) concluded that the failure and success of an entity depends upon the working relations beteen employer and employee ,further argued that success of privatization solely depends on better working ties with workers.

Sam Q. Ziorkui etal, Howard (2001) carried research regarding customers' point view after privatization of banks .It was revealed that new products were innovated, services were significantly improved, and internal environment was enhanced.

\section{Data Collection \& Research Methodology}

This study is aimed at finding out the effect of privatization on the efficiency and performance of commercial banks in Pakistan. First privatized commercial Bank namely MCB Bank Limited (Formerly Muslim Commercial Bank Limited) has been selected for this purpose.

There are number of key performance indicators for analyzing the performance of commercial banks, most commonly the financial performance is measured by using combination of financial ratios meant for profitability, liquidity and solvency , other techniques include benchmarking and comparison the actual performance with budgeted .

\section{Interpretation of Primary Data}

Primary Data was collected from employees of MCB and customers of various branches located in Districts Khuzdar ,Kalat and Mastung of Balochistan comprising line, middle and top management \& customers of SME ,Consumer finance ,corporate and common low saving and high net worth customers, a closed ended questionnaire containing twenty five key areas was developed and results were analyzed as under.

\section{Comments:}

\section{Results of Primary Data}

It has been concluded that,

After Privatization MCB bank has developed new products, improved its quality of services, reduced its turnaround time and internal environment of work place significantly enhanced. However bank has shown discrimination on the basis of business generated from customer with respect to deposits, advances, fee based income and non fee based income as being dealt in capitalist -market based economies. Rates of profits on deposits and advances are fixed at the disposal of bank on the basis of business given ie amount of deposit /advances and the common man is being dealt as per standard practices which exploit the common savers and investors. As far as advances are concerned priority shifted from agriculture to SME/Corporate clients and major portion is invested in government papers which are risk free and are source of steady income even Qard-e-Hassana scheme for poor students have been discontinued. It is also revealed that 
International Journal of Management and Information Technology unhealthy competition has been started among private banks; the customer gets undue benefit of it. Employees are dissatisfied as hiring and promotions are not purely on merit and wages are not matched with market; their participation in business divisions is minimal and style of management prevails which has de-motivated the staff. Moreover their benefits have been curtailed particularly overtime and medical, even profit bonuses are paid on the basis of favoritism or so called pay for performance. Staff internal recruitment for career progression remained suspended.

Secondary Data

\begin{tabular}{|c|c|c|c|c|c|c|c|c|c|c|c|}
\hline & 2002 & 2003 & 2004 & 2005 & 2006 & 2007 & 2008 & 2009 & 2010 & 2011 & 2012 \\
\hline Profit Before Tax & $\begin{array}{l}33.83 \\
\%\end{array}$ & $\begin{array}{l}34.84 \\
\%\end{array}$ & $\begin{array}{l}44.67 \\
\%\end{array}$ & $\begin{array}{l}73.32 \\
\%\end{array}$ & $\begin{array}{l}71.77 \\
\%\end{array}$ & $\begin{array}{l}67.03 \\
\%\end{array}$ & $\begin{array}{l}54.61 \\
\%\end{array}$ & $\begin{array}{l}44.86 \\
\%\end{array}$ & $\begin{array}{l}47.89 \\
\%\end{array}$ & $\begin{array}{l}46.20 \\
\%\end{array}$ & $\begin{array}{l}46.89 \\
\%\end{array}$ \\
\hline $\begin{array}{l}\text { Gross Yield on } \\
\text { Advances }\end{array}$ & $4.89 \%$ & $4.98 \%$ & $5.27 \%$ & $7.78 \%$ & $\begin{array}{l}10.12 \\
\%\end{array}$ & $\begin{array}{l}10.03 \\
\%\end{array}$ & $\begin{array}{l}11.47 \\
\%\end{array}$ & $\begin{array}{l}12.47 \\
\%\end{array}$ & $\begin{array}{l}12.03 \\
\%\end{array}$ & $\begin{array}{l}13.01 \\
\%\end{array}$ & $\begin{array}{l}11.38 \\
\%\end{array}$ \\
\hline $\begin{array}{ll}\text { Gross } & \text { Spread } \\
\text { Ratio } & \end{array}$ & $\begin{array}{l}60.52 \\
\%\end{array}$ & $\begin{array}{l}71.72 \\
\%\end{array}$ & $\begin{array}{l}77.34 \\
\%\end{array}$ & $\begin{array}{l}84.34 \\
\%\end{array}$ & $\begin{array}{l}82.44 \\
\%\end{array}$ & $\begin{array}{l}75.26 \\
\%\end{array}$ & $\begin{array}{l}71.13 \\
\%\end{array}$ & $\begin{array}{l}69.31 \\
\%\end{array}$ & $\begin{array}{l}67.19 \\
\%\end{array}$ & $\begin{array}{l}65.34 \\
\%\end{array}$ & $\begin{array}{l}59.77 \\
\%\end{array}$ \\
\hline Cost/Income Ratio & $\begin{array}{l}68.02 \\
\%\end{array}$ & $\begin{array}{l}67.26 \\
\%\end{array}$ & $\begin{array}{l}66.36 \\
\%\end{array}$ & $\begin{array}{l}34.50 \\
\%\end{array}$ & $\begin{array}{l}25.13 \\
\%\end{array}$ & $\begin{array}{l}20.71 \\
\%\end{array}$ & $\begin{array}{l}27.65 \\
\%\end{array}$ & $\begin{array}{l}31.67 \\
\%\end{array}$ & $\begin{array}{l}33.32 \\
\%\end{array}$ & $\begin{array}{l}34.68 \\
\%\end{array}$ & $\begin{array}{l}35.66 \\
\%\end{array}$ \\
\hline Return on Equity & $\begin{array}{l}30.77 \\
\%\end{array}$ & $\begin{array}{l}28.86 \\
\%\end{array}$ & $\begin{array}{l}26.44 \\
\%\end{array}$ & $\begin{array}{l}48.72 \\
\%\end{array}$ & $\begin{array}{l}34.07 \\
\%\end{array}$ & $\begin{array}{l}37.66 \\
\%\end{array}$ & $\begin{array}{l}30.31 \\
\%\end{array}$ & $\begin{array}{l}27.35 \\
\%\end{array}$ & $\begin{array}{l}25.91 \\
\%\end{array}$ & $\begin{array}{l}26.23 \\
\%\end{array}$ & $\begin{array}{l}25.07 \\
\%\end{array}$ \\
\hline $\begin{array}{l}\text { Return on Capital } \\
\text { Employed }\end{array}$ & $\begin{array}{l}30.77 \\
\%\end{array}$ & $\begin{array}{l}28.86 \\
\%\end{array}$ & $\begin{array}{l}26.44 \\
\%\end{array}$ & $\begin{array}{l}48.72 \\
\%\end{array}$ & $\begin{array}{l}34.07 \\
\%\end{array}$ & $\begin{array}{l}37.66 \\
\%\end{array}$ & $\begin{array}{l}30.31 \\
\%\end{array}$ & $\begin{array}{l}27.35 \\
\%\end{array}$ & $\begin{array}{l}25.91 \\
\%\end{array}$ & $\begin{array}{l}26.23 \\
\%\end{array}$ & $\begin{array}{l}25.07 \\
\%\end{array}$ \\
\hline Gross Profit Ratio & $\begin{array}{l}45.32 \\
\%\end{array}$ & $\begin{array}{l}44.67 \\
\%\end{array}$ & $\begin{array}{l}50.66 \\
\%\end{array}$ & $\begin{array}{l}59.69 \\
\%\end{array}$ & $\begin{array}{l}65.23 \\
\%\end{array}$ & $\begin{array}{l}55.18 \\
\%\end{array}$ & $\begin{array}{l}53.37 \\
\%\end{array}$ & $\begin{array}{l}49.69 \\
\%\end{array}$ & $\begin{array}{l}54.41 \\
\%\end{array}$ & $\begin{array}{l}53.60 \\
\%\end{array}$ & $\begin{array}{l}52.09 \\
\%\end{array}$ \\
\hline Net Profit to Sales & $\begin{array}{l}14.83 \\
\%\end{array}$ & $\begin{array}{l}14.96 \\
\%\end{array}$ & $\begin{array}{l}18.26 \\
\%\end{array}$ & $\begin{array}{l}38.51 \\
\%\end{array}$ & $\begin{array}{l}39.48 \\
\%\end{array}$ & $\begin{array}{l}40.39 \\
\%\end{array}$ & $\begin{array}{l}33.54 \\
\%\end{array}$ & $\begin{array}{l}27.06 \\
\%\end{array}$ & $\begin{array}{l}27.62 \\
\%\end{array}$ & $\begin{array}{l}25.47 \\
\%\end{array}$ & $\begin{array}{l}27.02 \\
\%\end{array}$ \\
\hline Return on Assets & $0.82 \%$ & $0.82 \%$ & $0.94 \%$ & $2.99 \%$ & $\begin{array}{l}3.55 \\
\%\end{array}$ & $3.72 \%$ & $\begin{array}{l}3.58 \\
\%\end{array}$ & $\begin{array}{l}3.25 \\
\%\end{array}$ & $\begin{array}{l}3.13 \\
\%\end{array}$ & $\begin{array}{l}3.18 \\
\%\end{array}$ & $\begin{array}{l}2.95 \\
\%\end{array}$ \\
\hline $\begin{array}{l}\text { NFI to Total } \\
\text { Income }\end{array}$ & $\begin{array}{l}21.76 \\
\%\end{array}$ & $\begin{array}{l}37.86 \\
\%\end{array}$ & $\begin{array}{l}37.60 \\
\%\end{array}$ & $\begin{array}{l}26.55 \\
\%\end{array}$ & $\begin{array}{l}19.02 \\
\%\end{array}$ & $\begin{array}{l}20.08 \\
\%\end{array}$ & $\begin{array}{l}16.90 \\
\%\end{array}$ & $\begin{array}{l}13.62 \\
\%\end{array}$ & $\begin{array}{l}14.54 \\
\%\end{array}$ & $\begin{array}{l}15.41 \\
\%\end{array}$ & $\begin{array}{l}18.30 \\
\%\end{array}$ \\
\hline $\begin{array}{l}\text { Gross Advances to } \\
\text { Deposits Ratio }\end{array}$ & $\begin{array}{l}43.20 \\
\%\end{array}$ & $\begin{array}{l}51.16 \\
\%\end{array}$ & $\begin{array}{l}66.11 \\
\%\end{array}$ & $\begin{array}{l}82.29 \\
\%\end{array}$ & $\begin{array}{l}80.34 \\
\%\end{array}$ & $\begin{array}{l}78.65 \\
\%\end{array}$ & $\begin{array}{l}82.64 \\
\%\end{array}$ & $\begin{array}{l}73.37 \\
\%\end{array}$ & $\begin{array}{l}63.55 \\
\%\end{array}$ & $\begin{array}{l}50.52 \\
\%\end{array}$ & $\begin{array}{l}48.14 \\
\%\end{array}$ \\
\hline $\begin{array}{ll}\text { Investments } & \text { to } \\
\text { Deposits Ratio } & \end{array}$ & $\begin{array}{l}55.02 \\
\%\end{array}$ & $\begin{array}{l}60.65 \\
\%\end{array}$ & $\begin{array}{l}30.40 \\
\%\end{array}$ & $\begin{array}{l}30.30 \\
\%\end{array}$ & $\begin{array}{l}24.66 \\
\%\end{array}$ & $\begin{array}{l}38.72 \\
\%\end{array}$ & $\begin{array}{l}29.27 \\
\%\end{array}$ & $\begin{array}{l}45.47 \\
\%\end{array}$ & $\begin{array}{l}49.39 \\
\%\end{array}$ & $\begin{array}{l}64.47 \\
\%\end{array}$ & $\begin{array}{l}73.77 \\
\%\end{array}$ \\
\hline $\begin{array}{l}\text { Cash \& Portfolio } \\
\text { Inv to Deposits }\end{array}$ & $\begin{array}{l}70.08 \\
\%\end{array}$ & $\begin{array}{l}72.02 \\
\%\end{array}$ & $\begin{array}{l}41.18 \\
\%\end{array}$ & $\begin{array}{l}40.61 \\
\%\end{array}$ & $\begin{array}{l}37.27 \\
\%\end{array}$ & $\begin{array}{l}52.30 \\
\%\end{array}$ & $\begin{array}{l}41.27 \\
\%\end{array}$ & $\begin{array}{l}56.01 \\
\%\end{array}$ & $\begin{array}{l}59.92 \\
\%\end{array}$ & $\begin{array}{l}75.28 \\
\%\end{array}$ & $\begin{array}{l}84.30 \\
\%\end{array}$ \\
\hline $\begin{array}{l}\text { Earning Assets } \\
\text { toTotal Assets }\end{array}$ & $\begin{array}{l}85.93 \\
\%\end{array}$ & $\begin{array}{l}86.73 \\
\%\end{array}$ & $\begin{array}{l}83.90 \\
\%\end{array}$ & $\begin{array}{l}88.96 \\
\%\end{array}$ & $\begin{array}{l}83.45 \\
\%\end{array}$ & $\begin{array}{l}83.60 \\
\%\end{array}$ & $\begin{array}{l}85.38 \\
\%\end{array}$ & $\begin{array}{l}87.23 \\
\%\end{array}$ & $\begin{array}{l}87.15 \\
\%\end{array}$ & $\begin{array}{l}87.14 \\
\%\end{array}$ & $\begin{array}{l}86.61 \\
\%\end{array}$ \\
\hline $\begin{array}{l}\text { Deposits to Equity } \\
\text { Ratio }\end{array}$ & $\begin{array}{l}2893.6 \\
6 \%\end{array}$ & $\begin{array}{l}2737.6 \\
5 \%\end{array}$ & $\begin{array}{l}2403.1 \\
9 \%\end{array}$ & $\begin{array}{l}1252.5 \\
0 \%\end{array}$ & $\begin{array}{l}722.0 \\
5 \%\end{array}$ & $\begin{array}{l}720.60 \\
\%\end{array}$ & $\begin{array}{l}650.7 \\
0 \%\end{array}$ & $\begin{array}{l}648.7 \\
9 \%\end{array}$ & $\begin{array}{l}662.3 \\
4 \%\end{array}$ & $\begin{array}{l}663.3 \\
4 \%\end{array}$ & $\begin{array}{l}618.2 \\
8 \%\end{array}$ \\
\hline $\begin{array}{l}\text { Deposits to Total } \\
\text { Assets }\end{array}$ & $\begin{array}{l}77.70 \\
\%\end{array}$ & $\begin{array}{l}77.67 \\
\%\end{array}$ & $\begin{array}{l}85.30 \\
\%\end{array}$ & $\begin{array}{l}76.76 \\
\%\end{array}$ & $\begin{array}{l}75.26 \\
\%\end{array}$ & $\begin{array}{l}71.16 \\
\%\end{array}$ & $\begin{array}{l}74.15 \\
\%\end{array}$ & $\begin{array}{l}72.19 \\
\%\end{array}$ & $\begin{array}{l}76.01 \\
\%\end{array}$ & $\begin{array}{l}75.19 \\
\%\end{array}$ & $\begin{array}{l}71.17 \\
\%\end{array}$ \\
\hline Equity Multiplier & $\begin{array}{l}37.24 \\
\%\end{array}$ & $\begin{array}{l}3524.7 \\
7 \%\end{array}$ & $\begin{array}{l}2817.4 \\
1 \%\end{array}$ & $\begin{array}{l}1631.6 \\
8 \%\end{array}$ & $\begin{array}{l}959.4 \\
4 \%\end{array}$ & $\begin{array}{l}1012.6 \\
6 \%\end{array}$ & $\begin{array}{l}877.7 \\
7 \%\end{array}$ & $\begin{array}{l}898.7 \\
3 \%\end{array}$ & $\begin{array}{l}871.7 \\
4 \%\end{array}$ & $\begin{array}{l}882.1 \\
8 \%\end{array}$ & $\begin{array}{l}868.7 \\
9 \%\end{array}$ \\
\hline
\end{tabular}

\section{Analysis \& Interpretation of Secondary Data:}

While going through the ratio analysis it was found that the period under review bank has performed very well in terms of growth with respect to profitability, liquidity and solvency.

Cost of doing the business was significantly contained, income was improved. Its cost income ratio shows that it declined from $68 \%$ to $36 \%$ with average around $40 \%$ which is remarkable achievement. The cost income ratio is correlation between operational activities ie operational income versus operational expenses. During the period under review bank has improved its income and reduced its cost of operations considerably even it touched to around $70 \%$ which is a positive indicator shows that bank was working on sound footings. 

Profit before tax ratio was improved from $33 \%$ to $47 \%$ it touched to $73 \%$ in 2005 which declined in 2006 and onward due to reduction in spread as the small and mid tier banks were mobilizing costly deposits in market place which compelled bank's top management to adopt flexible behavior to capture as well as maintain its market share in tough competition. It was very much positive point that bank's overall deposit composition remained quite better ie around $89 \%$ of its deposits were in CASA (Current Account Saving Accounts) on which either no profit was profit or normal low rate was paid which saved its cost of deposit mobilization. The Profit before Tax (PBT) ratio reveals that substantial rise in mark up and non markup income was witnessed after privatization and better deposit mix was managed through targeted efforts, around 90 $\%$ of deposit pertains to either low cost or no cost which has supported the bank to post a better profit as markup expense has been contained substantially. Moreover bank has worked on generation of markup income considerably as it has adopted sound credit policies and risk mitigation techniques to avert loss on NPLs and selection of quality risk assets.

The gross profit ratio is also indicator of its better management it improved from $45 \%$ to $52 \%$ although it touched to $65 \%$ but after emergence of financial crisis it remained somehow disturbed. Overall it remained quite stable at the average of $53 \%$. The gross yield on advances was also quite improving on year on year basis ,it was around $5 \%$ in 2002 which touched to $11 \%$ in 2012 ,it shows better monitoring of its risk assets to contain the non performing loans in manageable limits. It also portrays the better managerial policies that were put in place to avoid any compromise over quality of its advances portfolio.

The ratio of return on assets is also indicator that bank was focused to avoid leakage of income on idle assets therefore it has managed its assets in a better way to earn on income by utilizing its assets in safe and secure mode of investment particularly in government securities which lead to better profit without any risk. The ratio improved from $0.82 \%$ to $2.95 \%$ with average of $2.63 \%$.

The ratio of net profit to sales was increasing trend it was around $15 \%$ in 2002 which touched to $40 \%$ in 2007 and was decreased to $27 \%$ in 2012 with average around $28 \%$ It tells that Gross profit is ever increasing but was slowdown after 2007 for the reason of international stress in financial markets which reduced mark up income although banks were engaged in other sources like Banca business to fill the gap which was somehow improved profitability of banking sector in short run.

The return on equity remained stable during the period under review despite trouble in financial market in 2008 -2010 due to emergence of global financial crisis. The bank was in a very strong position in terms of equity and Capital Adequacy ratio (CAR) , CAR was more than $22 \%$ against its international standard of $8 \%$ which shows that bank is very much stable in terms of long term solvency as it has a sound capital base and more buffer is provided against its risk weighted assets(RWA)

Equity multiplier is a measurement of a company's financial leverage. Companies purchase of assets by raising debt or through equity.

MCB Bank witnessed the decline in the ratio over the period that is proof of their strong \& in time foresight and lesser reliance on debts for increasing their asset base. The assets were financed by the equity which was raised also in compliance to Basel-II accord.

\section{Conclusion}

\section{Primary Data reveals}

- Innovated new products to cater the emerging needs of customers

- Improved its quality of services, reduced its turnaround time

- Enhanced its interior decoration and internal environment of work place signify

- Displayed capitalist approach by discriminating customers on the basis of business generated from customer.

- Rates of profits on deposits and advances are fixed at the disposal of bank on the basis of business given i.e. amount of deposit /advances.

- General Public /common man is being dealt as per standard practices which exploit the common savers and investors.

- Agriculture is back bone of economy which was ignored and loans were extended to SME/Corporate clients.

- Qard-e-Hassana scheme for poor students have been discontinued.

- Unhealthy competition has been started among private banks; the customer gets undue benefit of it.

- Employees are dissatisfied as hiring and promotions are not purely on merit and wages are not matched with market.

- $\quad$ No participation of staff in business decisions which has de-motivated the staff.

- Staff benefits have been curtailed which compelled staff for frequent swith over to other banks.

- Staff internal recruitment for career progression remained suspended.

\section{The Secondary Data reveals}

- Cost of doing the business was significantly contained, income was improved. Its cost income ratio shows that it declined from $68 \%$ to $36 \%$ with average around $40 \%$ which is remarkable achievement.

- The cost income ratio is correlation between operational activities i.e. operational income versus operational expenses. During the period under review bank has improved its income and reduced its cost of operations 
nternational Journal of Management and Information Technology considerably even it touched to around $70 \%$ which is a positive indicator shows that bank was working on sound footings.

- Profit before tax ratio was improved from $33 \%$ to $47 \%$ it touched to $73 \%$ in 2005 which declined in 2006 and onward

- It was very much positive point that bank's overall deposit composition remained quite better ie around $89 \%$ of its deposits were in CASA (Current Account Saving Accounts) on which either no profit was profit or normal low rate was paid which saved its cost of deposit mobilization.

- The Profit before Tax (PBT) ratio reveals that substantial rise in mark up and non markup income was witnessed after privatization and better deposit mix supported the bank to post a better profit.

- Bank has adopted sound credit policies and risk mitigation techniques to avert loss on NPLs and selection of quality risk assets.

- The gross profit ratio is also indicator of its better management it improved from $45 \%$ to $52 \%$ although it touched to $65 \%$

- The gross yield on advances was also quite improving on year on year basis ,it was around $5 \%$ in 2002 which touched to $11 \%$ in 2012 , it shows better monitoring of its risk assets to contain the non performing loans in manageable limits

- The ratio of return on assets is also indicator that bank was focused to avoid leakage of income on idle assets, the ratio improved from $0.82 \%$ to $2.95 \%$ with average of $2.63 \%$.

- The ratio of net profit to sales was increasing trend it was around $15 \%$ in 2002 which touched to $40 \%$ in 2007 and was decreased to $27 \%$ in 2012 with average around $28 \%$ It tells that Gross profit is ever increasing.

- $\quad$ The return on equity remained stable during the period under review despite trouble in financial market in 2008 2010 due to emergence of global financial crisis.

- The bank was in a very strong position in terms of equity and Capital Adequacy ratio (CAR), CAR was more than $22 \%$ against its international standard of $8 \%$ which shows that bank is very much stable in terms of long term solvency as it has a sound capital base and more buffer is provided against its risk weighted assets(RWA)

- The equity multiplier is a measurement of a company's financial leverage. Companies finance the purchase of assets either through equity or debt. The bank witnessed the decline in the ratio over the period that is proof of their strong \& in time foresight and lesser reliance on debts for increasing their asset base. The assets were financed by the equity which was raised also in compliance to Basel-II accord.

\section{Recommendations \& Suggestions}

\section{Equal Treatment to Customers}

It has been revealed during research study that private banks do not treat all customers equally; High net worth customers have more benefits than that of common customers. Regulator and policy makers should take note of this unhealthy attitude of private banks to ensure that customers and common man is dealt equally in all transaction so that poor should not bear extra burden of bank charges for the nominal services provided to them instead rich are availing maximum facilities at lower rate which is clear exploitation of middle and lower middle class.

\section{Reduction in Spread Income:}

After privatization state bank allowed all commercial banks to fix their own rate of interest (mark up) on the case to case based on the customer's profile, risk rating and demand \& Supply principal to allow healthy competition in market place. It is very much strange that consumer loans attract highest rate of mark up. The consumer loans are allowed to common man for improving the standard of life but at the highest cost (markup). Regulators and federal government should take note of it to safe guard the interest of general public either they are savers or investors. Further a cap on rate of interest must be fixed by regulators so that common man could avail financing facilities at reason able cost to improve its standard of life.

\section{Reduction in Staff Strength:}

After privatization banks have started reduction of staff and their benefits in the name of right sizing whereas in fact the staff in actual is short if compared to business terms before and after denationalization .In first stage MCB had started retrenchment of low cost employees such as drivers and guards by replacing staff on contract from outsourced companies. Hence no one raise voice for exploitation of labor force. Moreover inducted more grades in hierarchy to curtail and control the benefits of next hire grades. After denationalization MCB Bank Limited changed the HR policies to maximize profit by reduction staff benefits particularly discontinuation of pension, conversion of permanent executive to contract based system, cease of provident fund balance of officers and executive.

Federal authorities should take care of its people by establishing in independent authority to look after the affairs of private sector employees and should ensure that the wages and benefits are linked with profit generation as the profit is outcome of untiring efforts of work force who is only factor of production that generates desired goals in service sector in general and financial sector in particular. Federal authorities should devise strict policy for award of minimum percentage of bonus 

to employees connected with their grades and maximum limit for top management should be fixed to avoid unnecessary favoritism to upper grades.

\section{Private Banks engaged in non core banking business:}

Privatized banks has entered into non-core bank activities with collaboration of insurance companies which in log run hardly hit the fame and repute of banks. In banca business at the booking of new business around $50 \%$ income goes to bank and its officials and remaining to banking companies who have nothing to do but to maintain file ,strangely noted that the companies are not interested in renewal premiums and majority of customers depend on banks. Therefore Regulator should monitor or strictly restrict non core activities of banks just for short term gains.

\section{Advances to Private Sector}

Advances play an important role in economic growth and development of an economy. One of the important objectives of nationalization of banks in 1974 was to provide credit to ever ignored priority sectors in line with government planning strategy by expanding network throughout the country to utilize savings of public in a better manner to ensure and accelerate the pace of economic growth. But after decades still banks are reluctant to extend loans to needy sectors of economy especially privatized /denationalized banks. Banks avoid financing rather engaged in investment in government securities which are risk free and earn steady income even agriculture sector the back bone of economy is ignored

Federal authorities and regulators should seriously view this issue and allocate minimum credit ceiling for advances to priority sectors preferably agriculture to discourage and discontinue informal lending which will surely reduce input cost of crop and will surely uplift standard of living of the population concerned with this sector.

\section{Accumulation of Bad Loans}

As stated above banks have diverted towards investment in government papers. Despite that heavy accumulation of bad loans itself tells that banks are not filtering the borrowers properly before granting the Loans which has resulted into write offs every year, on one hand it badly affects the profitability of banks and is loss of government revenue/tax on other hand.

Bank management is advised to ensure that proper risk is being measured and managed to avoid such heavy loss on account of non- performing loans which will surely improve the performance of banks.

Improve monitoring, surveillance and regulation: The authorities are required for continuous improvement in regulatory supervision to ensure justice and equality with all customers and to reduce spread as much as possible so that concentration of wealth in few hands could be avoided.

\section{Opening of branches in rural areas:}

It is observed that mostly branches are opened in banked area rather to unbanked area to compete with peer banks to generate business within the same vicinity instead of entering into new areas particularly villages and towns. The masses are living in villages and mostly depending on agri income. Resultantly majority of population remained unattended by this service industry.

Federal authorities and regulators should bound the banks to open new branches in far flung areas so that population could avail facilities at their doorsteps against reasonable charges which may further strengthen their deposit base as well as agri loans portfolio.

\section{Installation of ATMs:}

It has been observed that private banks normally takes decisions on the basis of ..........analysis hence normally ignore the masses residing in far flung areas. MCB Bank Limited also follows the footprints of private sector and has not provided ATM facilities to its all customer across the country. No of branches of MCB as per annual report of 2012 is 1187 where as no of ATMs is quite low i.e. 680.Managemnt should seriously take steps to provide ATM facility in all branches so that backward areas may also get benefit of this facility of modern era.

\section{Hidden Charges:}

It has also been explored that private banks do not clearly disclose the various costs being charged on processing of finance cases and after sanctioning of limits various hidden charges are recovered from customers which is also unfair. Regulators should seriously monitor the issue to ensure that no hidden charges are being recovered from clients. Moreover banks should make bound that customer awareness programs should be arranged and all the products must be advertised properly.

\section{Unhealthy competition in Market:}

It has also been revealed that smart customers are playing with private banks; they get offer letters for availing various facilities and placement of funds from various banks after much deliberation and discussion but they do not follow the terms and conditions of offer and move to next bank to get further better terms which has created a situation of unhealthy competition in market place. Some banks even enter into loss transactions for the sake of business generation which ultimately results in loss of equity and leads to mergers of small banks. Federal authorities should fix minimum charges 
International Journal of Management and Information Technology which should not be deviated so that private units may remain on track and should not face any equity problems to avoid mergers and amalgamation.

\section{Unjustified Work load:}

It has been noticed while research that staff in private banks is over loaded. Despite tremendous growth of business in terms of volume banks are reluctant to hire staff to support the team instead the employees are being compelled to deal with additional work with additional spent time without any compensation. Normally an employee serves more than ten hour a day at the expense of social and family life which has caused frustration in staff who is ready to quit the job but have no other recourse. Federal authorities must closely monitor this issue to ensure that staff is not exploited at any cost. In case of late sitting employees should be paid according to labour laws.

\section{References}

1. Ayub, Muhammad (1996), 'Appraisal of reforms introduced and need and scope for further reforms in Finacial Sector in Pakistan', Pakistan economic and social review 37(1) pp 27-39

2. Berger Allen N., Mester Loretta (1997), 'inside the black box: what explains differences in the efficiencies of financial institution? Journal of Banking and Finance (21)7 pp 35-38

3. Berger, A.N., Hancock, D. Humphery, D.B. (1993), 'Bank efficiency derived from the profit function, Journal of Ba finance pp-17.317-347

4. Berg, S.A., (1993), 'Bank efficiency in Nordic countries ', Journal of Banking and finance (17) 2-3, pp 39-45

5. Dario Focarelli, (1995), 'Are Mergers Beneficial to Consumers? Evidence from the market for bank Deposits', Bank of Italy, discussion paper 448, pp 25-36

6. Edward Altzman (1968),'Financial Ratios, Discriminate Analysis and prediction of Corporate Bankruptcies', Journal of Finance-1968 pp 21-28

7. Kalim Hyder, (1991), Financial sector Reforms \& Monetary Policy', Journal of Islamic Banking Vol. 8, pp 885895

8. K. Satyanarayana Dr.(1996), 'What Ails the Public Sector Banks in India-Need for strategic thrust' Journal of Indian Institute pp 4-9

9. Mangi Naveen A., ( 1996 ) 'Banking and Financial Sector Reforms after implementation', Pak. \& Gulf Economist, Vol.15 pp 521-543

10. Marakoon Bandra, (2002) 'Implications of financial sector reforms in Sri Lanka', pp 185-197

11. Pervaz Hasan, (1998), 'Pakistan Economy at the crossroads past policies and present imperatives', pp 51-84

12. Riaz Riazudin (2001), Pakistan: Financial Sector Assessment 1990-2000, pp 1-89

13. R. Tod Smith, (1998), 'Banking Competition and Macroeconomic Performance', Money Credit and Banking, Vol.26, pp 793-798

14. Salman Ahmed, ( 2003 ), Performance of Commercial Banks in Pakistan', Lahore School of Economics, pp 115

15. Sengupta, Arjun, ( 1995 ), 'Financial sector \& Economic Reforms', Economic and Political Weekly Vol.XXX pp 412-435

16. S. Rajagopal, ( 1996 ), 'Bank Risk Management A Risk Pricing Modle’, Oxford University Press, Oxford, pp 1014

17. Sultan Ahmed, ( 1998 ), 'Banking reforms imperative', Business, Daily Dawn

18. Tahir Andrabi \& Andera Ripa Di Meana, (1994), 'Banking Regulations and Debt Overhang', Money Credit and Banking, Vol. 26, part- No. 3, pp 460-475

19. Taseer Hadi Khalid and Company, (2000), 'Study on Banks operating in Pakistan', Banking survey, pp 13-72

20. W. S. Saraf, (1998), 'Banking Technology: Agenda Ahead', Oxford University Press, Oxford pp 153-155.

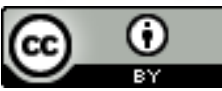

This work is licensed under a Creative Commons Attribution 4.0 International License.

D O I : 10.24297/ijmit.v12i1.6398 